\title{
Continuous Primary Fermentation of Beer with Yeast Immobilized on Spent Grains-The Effect of Operational Conditions
}

\author{
Tomáš Brányik and António A. Vicente, Centro de Engenharia Biológica, Universidade do Minho, Campus de \\ Gulatar, 4710-057 Braga, Portugal; José M. M. Cruz, UNICER—Bebidas de Portugal, S.A., Apartado 1044, 4466-955 \\ S. Mamede de Infesta, Portugal; and José A. Teixeira, ${ }^{1}$ Centro de Engenharia Biológica, Universidade do Minho, \\ Campus de Gulatar, 4710-057 Braga, Portugal
}

\section{ABSTRACT}

J. Am. Soc. Brew. Chem. 62(1):29-34, 2004

\begin{abstract}
A one-stage continuous primary beer fermentation with immobilized brewing yeast was studied. The objective of the work was to optimize the operational conditions (aeration and temperature) in terms of volumetric productivity and organoleptic quality of green beer. The system consisted of an internal-loop airlift reactor and a carrier material prepared from spent grains (a brewing by-product). An industrial wort and yeast strain were used. The immobilized biomass (in amounts from two to sevenfold greater than free biomass) contributed $45-75 \%$ to the total fermentation. The volumetric productivity of the continuous system was as much as five times higher than that of the batch fermentation. An optimum higheralcohols-to-esters ratio in green beer was found at approximately $2 \mathrm{mg} / \mathrm{L}$ of oxygen dissolved in wort, mixing induced by pure $\mathrm{CO}_{2}$, and temperatures at $13-16^{\circ} \mathrm{C}$. At high total biomass concentration, the diacetyl formation was low, and the volumetric productivity of the system was high. Therefore, the amount of immobilized biomass in the reactor has to be kept at high concentration by regular replacement of the carrier losses.
\end{abstract}

Keyword: Immobilization

\section{RESUMEN}

Fermentación Primaria Continua de Cerveza con Levadura Inmovilizada en Granos Gastados-El Efecto de Condiciones Operacionales

Una fermentación primaria continua de una etapa de cerveza con levadura cervecera inmovilizada fue estudiada. El objetivo del trabajo era optimizar las condiciones operacionales (aireación y temperatura) en términos de la productividad volumétrica y calidad organoléptica de la cerveza verde. El sistema consistió de un reactor de transporte aéreo de lazo interno y un material portador preparado de granos gastados (un subproducto de elaboración de cerveza. Una cepa de levadura y mosto industrial fueron utilizados. La biomasa inmovilizada (en cantidades de dos a siete veces mas que la biomasa libre) contribuyó el $45-75 \%$ a la fermentación total. La productividad volumétrica del sistema continuo era tanto como cinco veces más que el de fermentación por etapas. Un cociente óptimo de alcohol alto a esteres en cerveza verde fue encontrado aproximadamente a $2 \mathrm{mg} / \mathrm{L}$ de oxígeno disuelto en mosto, mezclamiento inducido por el $\mathrm{CO} 2$ puro, y temperaturas de $13-16^{\circ} \mathrm{C}$. En alta concentración total de biomasa, la formación de diacetilo era baja, y la productividad volumétrica del sistema era alta. Por lo tanto, la cantidad de biomasa inmovilizada en el reactor tiene que ser guardada en alta concentración por el reemplazo regular de las pérdidas del portador.

Palabra clave: Inmovilización

Continuous beer fermentation offers a wide range of advantages, mostly of an economic origin over the traditional

\footnotetext{
${ }^{1}$ Corresponding author. Phone: +351 253 604406; Fax: +351 253 678986; E-mail: jateixeira@deb.uminho.pt
}

Publication no. J-2003-1216-01R.

(c) 2004 American Society of Brewing Chemists, Inc. batch process. Rapid processing, low capital and production costs, and high volumetric productivity are among the most repeated arguments in favor of continuous fermentation (10). Nevertheless, the increased productivity cannot be achieved at the expense of an unbalanced flavor profile of the final product and, therefore, process optimization is indispensable for any technological innovation (11).

Accelerated fermentation rates in continuous systems are often attained by means of yeast immobilization. Several factors, such as price, availability, stability, and high cell-load capacity of the support must be considered when choosing a cell immobilization system (13). For large-scale industrial applications, cell adsorption to porous solids (porous glass, diatomaceous earth, and silicon carbide) $(20,24)$ or cell adhesion and attachment to nonporous solid surfaces (wood chips, spent grains, and (diethylamino)ethylcellulose) $(7,9,25)$ are considered to be the most suitable immobilization strategy (12).

Spontaneous adhesion or attachment of brewing yeast to the surface of the nonporous cellulose-based carrier material prepared from spent grains (a brewing by-product) results in direct contact of the immobilized biomass with the bulk liquid substrates (1). Although the yeast immobilized on nonporous surfaces reduce mass transfer problems, the immobilized biomass tends to be rather sensitive to shear-force induced detachment from the support (2). It is therefore, necessary to minimize the shear force (e.g., by optimizing the gas flow rate in the reactor [an internalloop airlift in the current work]) to prevent the undesirable loss of the immobilized biocatalyst.

Another important objective of process optimization is to preserve the characteristics of the product while maintaining a high biomass concentration in the reactor, and thus, an improved volumetric productivity of the system. Continuous beer fermentation systems with immobilized yeast often produce a beer with a flavor profile distinct from that of beer fermented traditionally. Higher diacetyl content and lower concentration of esters in green beer have been reported (16). An adequate oxygen supply is necessary for sufficient biomass growth, though its excess may lead to growth related (amino acid metabolism) overproduction of vicinal diketones (14), decrease of ester synthesizing activity level of cells (8), as well as an increased level of acetaldehyde (6). Temperature is another parameter that affects not only the fermentation rate, but also the beer flavor through an altered diacetyl formation and conversion rate, different ester, higher alcohol and acetaldehyde production, and amino acid uptake (18). The aim of this work was to study the influence of these two parameters (aeration and temperature) on the volumetric productivity and organoleptic quality of the green beer.

\section{EXPERIMENTAL}

\section{Yeast Strain and Culture Conditions}

The brewing yeast, Saccharomyces pastorianus (carsbergensis), was supplied by UNICER, S.A. (S. Mamede de Infesta, Portugal). 
The yeast for inoculation of the continuous airlift reactor was cultivated in $500 \mathrm{~mL}$ of synthetic medium under aerobic conditions on a rotary shaker $(120 \mathrm{rpm})$ at $30^{\circ} \mathrm{C}$ for $30 \mathrm{hr}$. The composition of the synthetic medium was as follows: $\mathrm{KH}_{2} \mathrm{PO}_{4}$ at $5.0 \mathrm{~g} / \mathrm{L},\left(\mathrm{NH}_{4}\right)_{2} \mathrm{SO}_{4}$ at $2.0 \mathrm{~g} / \mathrm{L}, \mathrm{MgSO}_{4} \cdot 7 \mathrm{H}_{2} \mathrm{O}$ at $0.4 \mathrm{~g} / \mathrm{L}$, yeast extract at $1.0 \mathrm{~g} / \mathrm{L}$, and glucose at $10.0 \mathrm{~g} / \mathrm{L}$. Medium with the same composition was used in continuous experiments during biomass attachment. The all-malt wort used in this work had an original gravity of $14^{\circ} \mathrm{P}$ and was supplied by UNICER, S.A.

\section{Carrier Preparation}

Dry spent grains $(100 \mathrm{~g})$, obtained after dry roller milling of malt and wort separation, were mixed in $1,500 \mathrm{~mL}$ of $3 \%$ (vol) $\mathrm{HCl}$ solution at $60^{\circ} \mathrm{C}$ for $2.5 \mathrm{hr}$ to hydrolyze the residual starchy endosperm and embryo of the barley kernel present in the spent grains. The mixture was cooled, washed with water, and dried. The remaining solids (approximately $30 \mathrm{~g}$ ), mainly the husks of the barley grain, were partially delignified by shaking $(120 \mathrm{rpm})$ in $500 \mathrm{~mL}$ of $2 \%(\mathrm{w} / \mathrm{v}) \mathrm{NaOH}$ solution at $30^{\circ} \mathrm{C}$ for $24 \mathrm{hr}$. After being washed several times with water (until neutral $\mathrm{pH}$ ) and dried, the carrier (approximately $10 \mathrm{~g}$ ) was ready to be used. The drying steps applied in the preparation procedure were necessary only to quantify the yields. The preparation procedure gave a $10 \%$ yield (on a weight basis) from dry spent grains. The average surface area of one carrier particle was $\mathrm{S}=0.59 \mathrm{~mm}^{2}$ as determined by image analysis (22).

\section{Airlift Reactor (ALR)}

The ALR used in this work is of the concentric draught tube type with an enlarged top section for degassing and a total working volume of $6 \mathrm{~L}$ (Fig. 1). The dimensions of the reactor are as follows: total height $=90 \mathrm{~cm}$; downcomer's length $=60 \mathrm{~cm}$ and inside diameter $=7 \mathrm{~cm}$; draught tube length $=56 \mathrm{~cm}$, diameter $=$ $3.2 \mathrm{~cm}$, and thickness $=0.4 \mathrm{~cm}$; and cylindrical part's length $=$ $14.5 \mathrm{~cm}$ and diameter $=19.2 \mathrm{~cm}$. The angle between the conical sector and the main body was $51^{\circ}$. Gas was injected through a perforated plate (1-cm diameter) with seven holes, each of $0.5 \mathrm{~mm}$ in diameter, and placed $2.5 \mathrm{~cm}$ below the annulus of the riser or injected through a nozzle (1-mm diameter) immediately below the annulus of the riser. The outflow of the reactor was placed behind a sedimentation barrier, thus minimizing carrier losses. The temperature inside the reactor was maintained by means of a cooling coil connected to a refrigeration bath. The desired gas flow (air, $\mathrm{CO} 2$, and mixtures of both) was adjusted with a mass flow controller (Hastings 202D; Hastings Instruments, Hampton, VA).

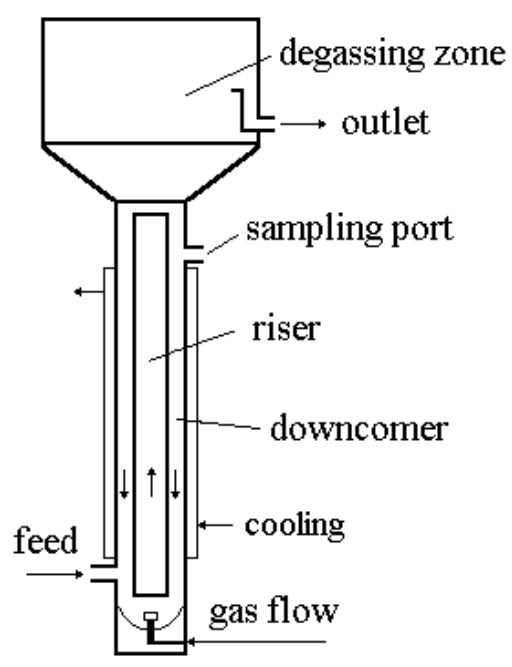

Fig. 1. Schematic representation of the airlift bioreactor.

\section{Starting and Operating of ALR}

The plexiglas ALR reactor was sterilized with sodium hypochlorite solution ( $2 \%$ active chlorine) at least four days prior to the start of the fermentation experiment. After draining the reactor, the sterile air supply was started, and the reactor was filled with the sterilized slurry $\left(40 \mathrm{~min}\right.$ at $\left.120^{\circ} \mathrm{C}\right)$ that consisted of pretreated spent grains (100 $\mathrm{g}$ dry state) in distilled water $(3 \mathrm{~L})$. Prior to inoculation, the reactor containing fresh carrier was washed with $50 \mathrm{~L}$ of sterile water. Subsequently, the reactor was charged with concentrated medium to obtain the desired concentration of the synthetic medium and then inoculated twice with $500 \mathrm{~mL}$ of yeast cell suspension grown by using a rotary shaker. At the end of a 24-hr batch growth, the feed of synthetic medium was started and it took approximately seven days at a dilution rate $(D)$ of $0.2 \mathrm{hr}^{-1}$ to reach an immobilized biomass load of approximately $0.25 \mathrm{~g}$ of dry cell per $\mathrm{g}$ of dry carrier. Dilution rates below $0.2 \mathrm{hr}^{-1}$ were not applied because they significantly prolonged the immobilization process (e.g., by 4 days at $D=0.15$ $\mathrm{hr}^{-1}$ [data not shown]). The synthetic medium was then changed to sterilized wort $\left(50 \mathrm{~L}\right.$ for $40 \mathrm{~min}$ at $\left.120^{\circ} \mathrm{C}\right)$ and $D=0.042 \mathrm{hr}^{-1}$ (flow rate of $250 \mathrm{~mL} / \mathrm{hr}$, residence time of $24 \mathrm{hr}$ ) was used throughout the whole fermentation experiment (2). The continuous system was considered to be in steady state conditions after a period of five residence times.

\section{Mixing Time}

Mixing time $\left(t_{\mathrm{m}}\right)$, defined as the time required for the variation of the $\mathrm{pH}$ value to be within $5 \%$ of the final equilibrium value, was determined by the $\mathrm{pH}$ pulse technique. A $\mathrm{pH}$ sensor was placed in the middle of the separator $(10 \mathrm{~cm}$ below the liquid level), and its signal was recorded after a pulse of $0.5 \mathrm{~mL}$ of $\mathrm{H}_{2} \mathrm{SO}_{4}(4.5 \mathrm{~mol} / \mathrm{L})$, and $0.5 \mathrm{~mL}$ of $\mathrm{NaOH}(5 \mathrm{~mol} / \mathrm{L})$ was injected into the downcomer ( $3 \mathrm{~cm}$ above the bottom of the reactor), at time zero. Three replicates were made for each set of experimental conditions (4).

\section{Analytical Methods}

Characterization of wort, green beer, and beer (specific gravity, original extract, degree of attenuation, alcohol, $\mathrm{pH}$, and color) was performed by SCABA 5600 (Automatic Beer Analyser; Tecator AB, Höganäs, Sweden). Total diacetyl was determined by gas chromatographic analysis of the static headspace (21). The flavor and aroma compounds (higher alcohols and esters) were measured according to the current European Brewery Convention recommended methods (3).

\section{Immobilized Biomass Determination}

A sample containing approximately $1.0 \mathrm{~g}$ of dry biocatalyst was taken from the reactor in a form of slurry through a sampling port in the downcomer, $50 \mathrm{~cm}$ above the bottom of the reactor. The bulk liquid was removed with a syringe, and the carrier was washed with $200 \mathrm{~mL}$ of distilled water. The carrier was filtered and washed with $400 \mathrm{~mL}$ of distilled water on a paper filter and dried at $105^{\circ} \mathrm{C}$ for $12 \mathrm{hr}$. An amount of approximately $0.5 \mathrm{~g}$ dry biocatalyst was weighed into an Erlenmeyer flask with $100 \mathrm{~mL}$ of $3 \%(\mathrm{w} / \mathrm{v}) \mathrm{NaOH}$ solution and shaken at $120 \mathrm{rpm}$ for $24 \mathrm{hr}$. During this time the attached biomass was completely removed from the carrier and this was verified with microscopy. The biomass free carrier was filtered and after being washed on the filter with 400 $\mathrm{mL}$ of distilled water, it was dried at $105^{\circ} \mathrm{C}$ for $5 \mathrm{hr}$. The amount of yeast biofilm was determined from the weight difference before and after the treatment with caustic. Corrections of the biomass weight for the losses of carrier itself (approximately 6\% wt) during the washing procedures were carried out with blank experiments with clean carrier. 


\section{RESULTS AND DISCUSSION}

\section{Effect of Gas Distributor and Airflow on Mixing Time in the ALR}

In three-phase internal-loop ALR, the gas phase is injected into the riser tube through a distributor to provide the driving force for the liquid circulation and the energy for the solid-phase distribution. To ensure an efficient mixing in the reactor (high liquid circulation velocities), the influence of the gas distributor on the energy transfer from the injected gas to the circulating liquid and its dissipation was studied. Two types of gas distributor (perforated plate and nozzle) were compared in terms of mixing time in the ALR charged with $150 \mathrm{~g}$ of spent grains suspended in water $(2.5 \%[\mathrm{w} / \mathrm{v}]$ solid load). The amount of spent grains $(150 \mathrm{~g})$ corresponds to a reactor solid load during primary beer fermentation consisting of $90 \mathrm{~g}$ of spent grains and approximately $60 \mathrm{~g}$ of dry cell weight per reactor. For both distributors, the mixing time first decreases with gas flow and then remains almost unchanged above $1.0 \mathrm{~L} / \mathrm{min}$ (Fig. 2). In the whole range of studied gas flow rates, the perforated plate showed lower mixing times than did the nozzle. Further, the perforated plate allowed maintaining circulation and solid-phase homogenization in the ALR at low gas flow rates $(0.16 \mathrm{~L} / \mathrm{min})$ where the nozzle distributor already failed. Since the perforated plate gas distributor guaranteed reliable operational conditions at low total gas flow rates, it was applied throughout the whole fermentation experiments.

\section{Stability of the Immobilized Biomass in the ALR}

The detachment of the biomass immobilized onto spent grains under conditions of mechanical stress had already been reported (2). Besides mechanical agitation, damage of the immobilized yeast biofilm can occur also as a consequence of aeration rate, which is the driving force of the liquid circulation in ALR. The influence of gas flow causing shear stress on steady state immobilized biomass load per gram of dry carrier $\left(X_{\mathrm{im}}\right)$ was studied during primary beer fermentation in an ALR with a perforated plate as a gas distributor (Fig. 2). It was found that an increase in gas flow from 0.16 to 0.57 and further to $1.04 \mathrm{~L} / \mathrm{min}$ resulted in up to $15 \%$ decrease of the $X_{\mathrm{im}}$. To avoid the yeast biofilm losses caused by high turbulence inside the reactor and to minimize the risk of biocatalyst sedimentation, a low total gas flow rate (different mixtures of air and $\mathrm{CO}_{2}$ were used) had to be applied during the primary fermentation. The total gas flow of $0.25 \mathrm{~L} / \mathrm{min}$ was a good compromise between mixing time, biocatalyst sedimentation, and the maximum $X_{\text {im }}$ (Fig. 2).

Despite the considerable mechanical stability of the spent grains carrier, its gradual disintegration and wash out was observed. The slow crumbling of the carrier particles was probably caused by collisions between the spent grains particles and between these and the reactor walls. Because of that, the smallest carrier particles were not separated from the outflow behind the sedimentation barrier of the ALR and were gradually washed out with an average rate of approximately $0.4 \mathrm{~g}$ of dry carrier per day as estimated from the material balance before and after the continuous experiments.

However, the ability of the brewing yeast to colonize the surface of the clean carrier, added at any stage of the continuous fermentation, allows the replacement of biocatalyst losses by washout and a high level of control and maintenance of the $X_{\mathrm{im}}$ in the reactor. On day 42 of the continuous beer fermentation experiment, $25 \mathrm{~g}$ of dry and clean spent grains were added to the ALR causing a proportional decrease of $X_{\mathrm{im}}$. Nevertheless, within one week after the addition of the fresh carrier, $X_{\text {im }}$ already returned to the original values resulting in the highest total biomass concentration of $X_{\mathrm{tot}}=14.95 \mathrm{~g} / \mathrm{L}$ (Fig. $3 \mathrm{~A}$ and B).

\section{Effect of the Aeration and Temperature on Cell Growth in the ALR}

The $X_{\text {im }}$ reached its maximum value after three days of feeding the reactor with wort and appeared to be nearly independent of reactor conditions (Fig. 3A). In contrast, the changes in the oxygen supply and fermentation temperature influenced the free biomass concentration $\left(X_{\text {free }}\right)$ and thus, the total biomass $\left(X_{\text {tot }}\right)$ in the reactor. Nevertheless, $X_{\text {free }}$ at different air flow (AF) rates and temperatures can not only be considered as a result of the altered growth kinetics of $X_{\text {free }}$ but it is also influenced by the changed growth rate of $X_{\mathrm{im}}$ and thus, different outgrowth (release and detachment) of cells from the yeast biofilm. Since the yeast growth during the primary beer fermentation is limited by the available dissolved oxygen, the $X_{\text {free }}$ in the reactor grew with the increasing air flow (Fig. 3A) changing also the value of $X_{\text {tot }}$ (Fig. 3B). Therefore, depending on the amount of $X_{\text {free }}$, the $X_{\text {im }} / X_{\text {free }}$ ratio varied between 2.2 and 6.9. The effect of temperature on $X_{\mathrm{im}}$ can also be considered negligible, while the $X_{\text {free }}$ at a constant airflow $(\mathrm{AF}=0.05 \mathrm{~L} / \mathrm{min})$ increased significantly from 1.5 to 3.3 g/L at 10 and $16^{\circ} \mathrm{C}$, respectively (Fig. 3A).

At zero AF into the ALR, when the driving force of the circulation is pure $\mathrm{CO}_{2}(0.25 \mathrm{~L} / \mathrm{min})$, the $X_{\text {free }}$ in the ALR system was approximately $1.9 \mathrm{~g} / \mathrm{L}$ at 13 and $16^{\circ} \mathrm{C}$ (Fig. 3A). Considering the biomass to oxygen yield coefficient, $Y_{\mathrm{X} / \mathrm{O} 2}=$ approximately $950 \mathrm{~g}$ of biomass per $\mathrm{g}$ of $\mathrm{O}_{2}(20)$, the dissolved oxygen level in feed wort can be estimated at approximately $2 \mathrm{mg} / \mathrm{L}$, which originated from oxygen diffusion through permeable silicone feed tubing. The amount of molecular oxygen entering the reactor in wort at normal wort flow rate $(0.25 \mathrm{~L} / \mathrm{hr})$ is essential for the growth of the brewing yeast (synthesis of sterols and unsaturated fatty acids).

\section{Productivity of the Primary Beer Fermentation}

The extent of wort attenuation during primary beer fermentation is controlled by the $X_{\text {tot }}$ in the reactor and its metabolic activity. Wort, with an original extract of $14^{\circ} \mathrm{P}$, was attenuated to green beer in the one-stage ALR system with apparent extract in the outflow between 8 and $3^{\circ} \mathrm{P}$, while the corresponding values of real attenuation varied between 38 and $63 \%$ depending on $X_{\text {tot }}$ (Fig. 3B). $X_{\text {tot }}$, which is determining the fermentation rate, can be controlled by fermentation conditions (aeration and temperature), influencing mainly $X_{\text {free }}$ through cell growth, or by addition of clean carrier gradually colonized by yeast, increasing $X_{\text {im }}$ (Fig. 3B).

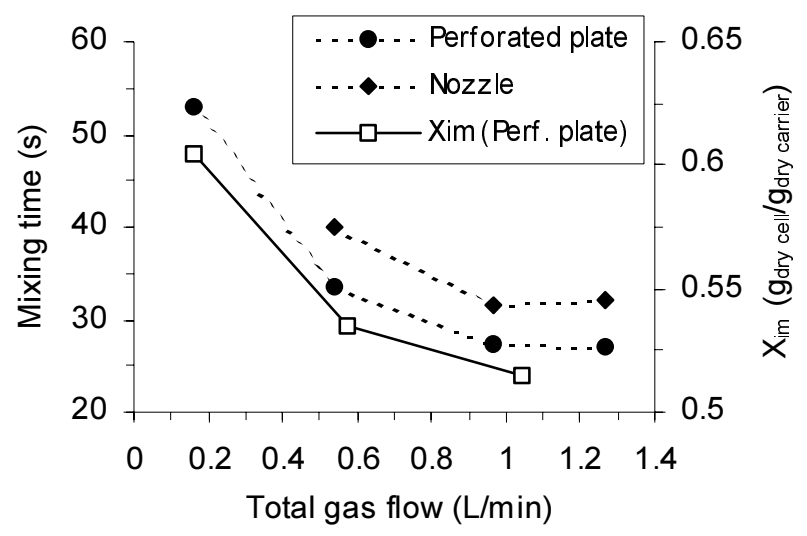

Fig. 2. The influence of the total gas flow (air) and distributor type on the mixing time in the airlift reactor (ALR) with $2.5 \%(\mathrm{w} / \mathrm{v})$ solid load (spent grains) in water, and the influence of the total gas flow (air) on the immobilized biomass $\left(X_{\mathrm{im}}\right.$, in grams of dry cell per grams of dry carrier) during wort fermentation $\left(14^{\circ} \mathrm{P}\right)$ in the ALR with $2.8 \%$ (w/v) solid load (spent grains and biomass). 
The higher air supply, higher fermentation temperature, or both, induced cell growth or increased the metabolic activity level, which led to a more extensive wort sugar consumption and ethanol production. From the known values of wort original
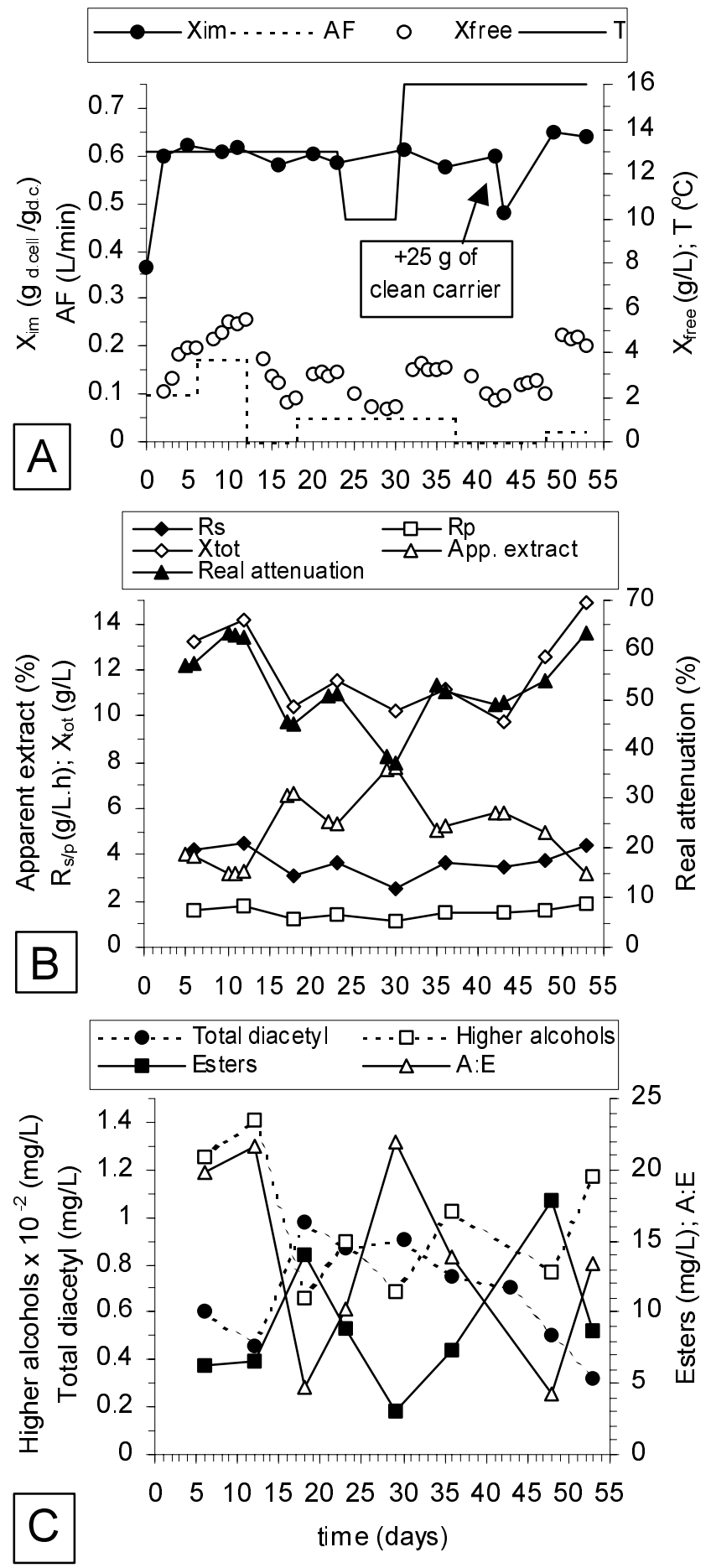

Fig. 3. Continuous primary beer fermentation with immobilized brewing yeast in the airlift reactor (ALR) at a constant dilution rate $(D)$ of 0.042 $\mathrm{hr}^{-1}$ and constant total gas flow rate (air $+\mathrm{CO}_{2}$ ) of $0.25 \mathrm{~L} / \mathrm{min}$. The influence of the proportion of air flow (AF) in the total gas flow rate and temperature $(T)$ on the following selected parameters of the primary fermentation and green beer composition: $\mathbf{A}$, immobilized $\left(X_{\mathrm{im}}\right)$ and free $\left(X_{\text {free }}\right)$ biomass concentration; $\mathbf{B}$, total $\left(X_{\text {tot }}\right)$ biomass concentration, real attenuation, apparent extract, volumetric sugar consumption rate $\left(R_{\mathrm{s}}\right)$, and volumetric ethanol production rate $\left(R_{\mathrm{p}}\right)$; and $\mathbf{C}$, concentration of total diacetyl, higher alcohols (A), esters (E), and $\mathrm{A} / \mathrm{E}$ ratio in green beer. extract (14\%), apparent extract of the green beer (Fig. 3B), and constant dilution rate $\left(D=0.042 \mathrm{hr}^{-1}\right)$, the volumetric productivities expressed as the rate of sugar consumption $\left(R_{\mathrm{s}}\right)$ and ethanol production $\left(R_{\mathrm{p}}\right)$ per unit reactor volume were calculated. Both volumetric productivities $\left(R_{\mathrm{s}}\right.$ and $\left.R_{\mathrm{p}}\right)$ showed values (Fig. $3 \mathrm{~B})$ similar to those found for a one-stage gas-lift bioreactor with yeast immobilized in pectate gel (19) and for a two-stage fluidized bed system with glass beads as carrier (20). The maximum $R_{\mathrm{s}}$ (approximately $4.2 \mathrm{~g} / \mathrm{L} / \mathrm{hr}$ ) in the ALR system with yeast immobilized on spent grains was significantly higher than was the average $R_{\mathrm{s}}$ (approximately $0.8 \mathrm{~g} / \mathrm{L} / \mathrm{hr}$ ) in batch fermentation considering a $14^{\circ} \mathrm{P}$ wort attenuated to $4^{\circ} \mathrm{P}$ apparent extract within five days.

Although it was possible to calculate the total specific sugar consumption rate $\left(q_{\mathrm{tot}}\right)$ from $R_{\mathrm{s}}$ and the respective $X_{\text {tot }}$, the $q_{\mathrm{tot}}$ values depend largely on reaction conditions (oxygen supply and temperature) and the metabolized substrate. Logically, $q_{\text {tot }}$ increased with increasing temperature and aeration rate until the green beer in the outflow from the ALR had a steady state apparent extract of approximately $4^{\circ} \mathrm{P}$ (data not shown). Because of the high degree of wort real attenuation (57\%), the yeast was already utilizing maltotriose, the least preferred sugar, and slowly metabolized the wort substrate showing a lower value of $q_{\text {tot }}$.

The $q_{\text {tot }}$ is not constant at different $X_{\text {im }} / X_{\text {free }}$ ratios, therefore, the metabolic activity level of the $X_{\text {free }}$ and immobilized $X_{\text {im }}$ cells cannot be considered equal. Knowing the value of $q_{\text {tot }}$ and the proportion of $X_{\mathrm{im}}$ and $X_{\text {free }}$ in $X_{\text {tot }}$ at different operating conditions, the specific sugar consumption rate of the immobilized $\left(q_{\mathrm{im}}\right)$ and free cells $\left(q_{\text {free }}\right)$ was estimated. For steady state fermentations below 52\% of real attenuation, the average $q_{\text {im }}$ and $q_{\text {free }}$ was $0.25 \pm 0.08 \mathrm{~g}$ of saccharides per $\mathrm{g}$ of immobilized biomass per $\mathrm{hr}$ and $0.63 \pm 0.10 \mathrm{~g}$ of saccharides per $\mathrm{g}$ of free biomass per $\mathrm{hr}$, respectively. It can be assumed, that similarly to the yeast flocs, the lower $q_{\mathrm{im}}$ is a result of a substrate diffusional limitation (fermentable sugars, oxygen) (23) into the multilayer yeast biofilm surrounding the spent grains particles or different physiological conditions of immobilized cells (17), or both. Despite the lower $q_{\mathrm{im}}$, the immobilized cells contribute with approximately $45-75 \%$ of the total fermentation in ALR (considering $X_{\mathrm{im}} / X_{\text {free }}$ ratio being in the range of 2.2 to 6.9 ).

Although the real attenuation and the volumetric and specific productivity are useful indicators of the fermentation efficiency, to evaluate the performance of the continuous ALR system with spent grains as a carrier for green beer production, it is essential to study the sensory compounds and the flavor profile of the green beer.

\section{Flavor and Aroma Profiles}

In the green beer produced in the ALR with brewing yeast immobilized on spent grains, the total diacetyl concentration largely varied depending on the operational conditions (Fig. 3C). However, under conditions of $X_{\text {tot }}$ achieved by increased aeration (Fig. 4), temperature, or carrier addition (Fig. 3C), the diacetyl concentration in green beer decreased to values of approximately $0.4 \mathrm{mg} / \mathrm{L}$. This is, at first sight, in apparent contradiction with the growth related (valine biosynthesis) origin of the diacetyl precursor $(\alpha$-acetolactate $)$ believed to be produced more intensively at high biomass growth rates. Therefore, the degree of wort attenuation and the metabolic activity level of brewing yeast have to be taken into account as well. It can be hypothesized that at conditions resulting in high $X_{\text {tot }}$ and low residual sugar concentration, the lower yeast growth rate on maltotriose originates less valine, consequently $\alpha$-acetolactate, and/or a significant absorption and sequential reduction of diacetyl to acetoin and 2,3-butanediol takes place. Moreover, the total diacetyl level in green beer between 0.4 and $0.6 \mathrm{mg} / \mathrm{L}$ was 
reduced in the final product below its taste threshold of $0.05 \mathrm{mg} / \mathrm{L}$ (10) after a maturation (batch) period of 10 days at $4{ }^{\circ} \mathrm{C}$.

Esters and higher alcohols are other volatile compounds characteristic of beer flavor and aroma profile. The higher alcohols are yeast growth related flavor compounds that are linked to amino acid metabolism of yeast (13). The formation of higher alcohols followed the pattern in batch fermentation (i.e., at high air feed $[\mathrm{AF}=0.174 \mathrm{~L} / \mathrm{min}]$ ) the formation of higher alcohols in green beer increased to approximately $140 \mathrm{mg} / \mathrm{L}$ (Fig. 3C). This was significantly more than the level of higher alcohols in the traditionally produced lager beer $(100 \mathrm{mg} / \mathrm{L})$ by the same yeast strain used in continuous experiments (Fig. 5). Concerning the desired concentration of higher alcohols in the final product $(100 \pm$ $10 \mathrm{mg} / \mathrm{L}$ ), the optimum AF was found in the range of 0.024 to 0.05 $\mathrm{L} / \mathrm{min}$. However, at these AF rates, the oxygen supply was critical for ester formation, not exceeding $10 \mathrm{mg} / \mathrm{L}$ in green beer. The oxygen probably inhibited the activity level of alcohol acetyltransferase, catalyzing the production of acetyl esters from acetyl-CoA, ethanol and higher alcohols (12). Optimum ester production (approximately $18 \mathrm{mg} / \mathrm{L}$ ) was achieved at zero AF (circulation induced by pure $\mathrm{CO}_{2}$ ) when oxygen was entering into the reactor only dissolved in feed wort (approximately $2 \mathrm{mg} / \mathrm{L}$ ).

The optimum higher-alcohols-to-esters ratio (A/E) in lager beers is considered to be between $4: 1$ and 4.7:1 (15). Both A/E ratios of 4.7 and 4.3:1 in green beer from the continuous system were achieved at zero AF (circulation induced by pure $\mathrm{CO}_{2}$ ) and temperatures at 13 and $16^{\circ} \mathrm{C}$, respectively (Fig. 3C). The green beer produced at day 48 of the continuous fermentation (Fig. 3C) had not only an optimum A/E ratio (4.3:1) but also a relatively low diacetyl content $(0.48 \mathrm{mg} / \mathrm{L})$ and a sufficient degree of real attenuation $(54 \%)$. This was achieved by increasing the $X_{\text {tot }}$ through addition and subsequent colonization of clean support by brewing yeast (leading to low diacetyl content and high fermentation rate) and by maintaining the air in the gas feed at zero (leading to optimum $\mathrm{A} / \mathrm{E}$ ratio).

The batch maturation ( 10 days at $4{ }^{\circ} \mathrm{C}$ ) of the continuously fermented green beer with $\mathrm{A} / \mathrm{E}$ ratio of $4.3: 1$ led to an approximately 5-10\% increase in higher alcohols and esters concentrations. The $\mathrm{A} / \mathrm{E}$ ratio in the lager beer produced by the industrial batch process was slightly higher $(5.4: 1)$ than that in beer produced by continuous primary fermentation and batch maturation (4.5:1). This can be partially ascribed to the difference between the original gravities of the wort used for batch $\left(13^{\circ} \mathrm{P}\right)$ and continuous $\left(14^{\circ} \mathrm{P}\right)$ fermentation. However, except for the slightly lower content of higher alcohols, there were no significant differences between the flavor and aroma profiles of the two lager beers (Fig. 5).

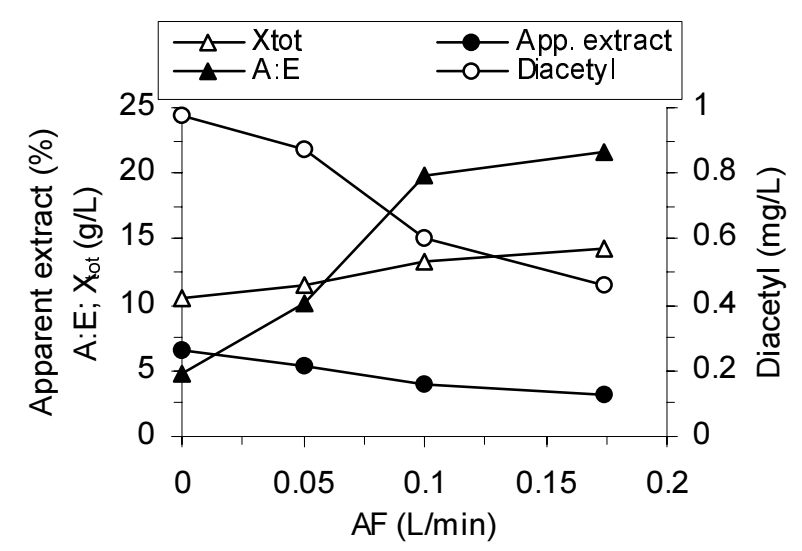

Fig. 4. Real attenuation, higher-alcohols-to-esters ratio (A/E), and total diacetyl concentration in green beer produced continuously in the airlift reactor at $13^{\circ} \mathrm{C}$ and with different air flow rates.
The results also demonstrated that at low fermentation temperatures $\left(10^{\circ} \mathrm{C}\right)$ the ester and higher alcohol formation was suppressed, negatively influencing the flavor and aroma profiles of the beer (data not shown). The effect of $\mathrm{CO}_{2}$ in the gas feed on growth and metabolism of yeast can be considered under the used experimental conditions (temperatures, unpressurized, and labscale ALR reactor) negligible (5).

\section{CONCLUSIONS}

The weak point of the brewing yeast immobilization onto spent grains carrier is its sensitivity towards shear stress. Therefore, the total gas flow rate and gas distributor type were optimized to avoid biomass detachment and carrier sedimentation. These conditions were then used in long-term continuous primary beer fermentation. It has been shown that the rate of the sugar consumption (volumetric productivity) of the presented system is competitive with other continuous systems developed so far $(19,20)$. Temperature and airflow rate have turned out to be efficient tools to control fermentation rate by means of their influence on biomass concentration. Independently of the operational conditions, the capability of the brewing yeast to colonize the clean support also allows control and maintenance of high biomass concentration inside the reactor by replacing the carrier losses during the fermentation. Although the specific sugar consumption rate by immobilized cells was approximately $40 \pm$ $20 \%$ lower comparing with free cells, the immobilized cells contributed $45-75 \%$ to the total fermentation in the system (considering $X_{\mathrm{im}} / X_{\text {free }}$ ratio being in the range of 2.2 to 6.9 ). This clearly shows that the immobilized biomass notably participates on the fermentation performance of the continuous system. The influence of the operational conditions on the sensory quality of green beer was also studied. Although the lager beer produced by continuous primary fermentation contained somewhat less higher alcohols compared with batch produced commercial lager beer, an optimum flavor and aroma profile of the continuously produced green beer were obtained at zero airflow in the gas feed (mixing induced by pure $\mathrm{CO}_{2}$ ) and temperatures between 13 and $16^{\circ} \mathrm{C}$. High volumetric productivity and low diacetyl formation were achieved at high values of the total biomass concentration in the system. To keep the biomass concentration in the reactor constantly high, the carrier losses by washout need to be regularly replaced.

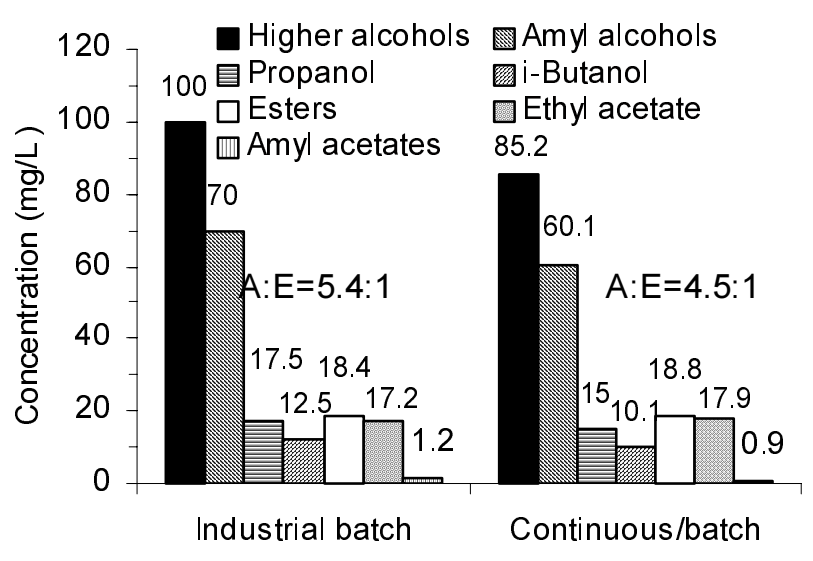

Fig. 5. Flavor and aroma compounds of two lager beers produced by the same yeast strain in an industrial batch process $\left(13^{\circ} \mathrm{P}\right.$ wort) and a continuous primary fermentation $\left(14^{\circ} \mathrm{P}\right.$ wort, temperature $=16^{\circ} \mathrm{C}$, and air flow $=0 \mathrm{~L} / \mathrm{min}$ ) followed by a batch maturation $\left(10\right.$ days at $\left.4^{\circ} \mathrm{C}\right)$. i-Butanol = iso-butanol. 


\section{ACKNOWLEDGMENT}

Financial support from FCT (Fundação para a Ciência e Tecnologia, SFRH / BPD / 3541 / 2000) is gratefully acknowledged.

\section{LITERATURE CITED}

1. Brányik, T., Vicente, A. A., Machado Cruz, J. M., and Teixeira, J. A. Spent grains-A new support for brewing yeast immobilization. Biotechnol. Lett. 23:1073-1078, 2001.

2. Brányik, T., Vicente, A. A., Machado Cruz, J. M., and Teixeira, J. A. Continuous primary beer fermentation with brewing yeast immobilized on spent grains. J. Inst. Brew. 108:410-415, 2002.

3. European Brewery Convention. Analytica EBC, -939 Dimethylsulphite and other lower boiling point volatile compounds in beer by gas chromatography. Fachverlag Hans Carl, Nürnberg, Germany, 2000.

4. Freitas, C., and Teixeira, J. A. Hydrodynamic studies in an airlift reactor with an enlarged degassing zone. Bioprocess Eng. 18:267279, 1998.

5. Knatchbull, F. B., and Slaughter, J. C. The effect of low $\mathrm{CO}_{2}$ pressures on the absorption of amino acids and production of flavour-active volatiles by yeast. J. Inst. Brew. 93:420-424, 1987.

6. Kronlöf, J., and Linko, M. Production of beer using immobilized yeast encoding $\alpha$-acetolactate decarboxylase. J. Inst. Brew. 98:479491, 1992.

7. Kronlöf, J., Härkönen, T., Hartwall, P., Home, S., and Linko, M. Main fermentation with immobilized yeast. Proc. Congr. Eur. Brew. Conv. 22:355-362, 1989.

8. Kuriyama, H., and Kobayashi, H. Effects of oxygen supply on yeast growth and metabolism in continuous fermentation. J. Ferment. Bioeng. 75:364-367, 1993.

9. Linko, M., Virkajärvi, I., Pohjala, N., Lindborg, K., Kronlöf, J., and Pajunen, E. Main fermentation with immobilized yeast-A breakthrough? Proc. Congr. Eur. Brew. Conv. 26:385-394, 1997.

10. Linko, M., Haikara, A., Ritala, A., and Penttilä, M. Recent advances in the malting and brewing industry. J. Biotechnol. 65:85-98, 1998.

11. Masschelein, C. A. A realistic view on the role of research in the brewing industry today. J. Inst. Brew. 103:103-113, 1997.

12. Masschelein, C. A., Ryder, D. S., and Simon, J. P. Immobilized cell technology in beer production. Crit. Rev. Biotechnol. 14:155-177, 1994.
13. Pajunen, E. The behaviour of immobilized yeast cells. Cerevisiae 4:33-37, 1996.

14. Pajunen, E., Grönqvist, A., and Lommi, H. Continuous secondary fermentation and maturation of beer in an immobilized yeast reactor. Tech. Q. Master Brew. Assoc. Am. 26:147-151, 1989.

15. Poledníková, M., Voborský, J., Chládek, L., and Šruma, T. Beer production using immobilized yeast on pilot plant scale (in Czech). Kvasný Prum. 39:2-7, 1993.

16. Ryder, D. S., and Masschelein, C. A. The growth process of brewing yeast and the biotechnological challenge. J. Am. Soc. Brew. Chem. 43:66-75, 1985.

17. Shen, H.-Y., Moonjai, N., Verstrepen, K. J., and Delvaux, F. R. Impact of attachment immobilization on yeast physiology and fermentation performance. J. Am. Soc. Brew. Chem. 61:79-87, 2003.

18. Šmogroviová, D., and Dömény, Z. Beer volatile by-product formation at different fermentation temperature using immobilized yeast. Process Biochem. 34:785-794, 1999.

19. Šmogroviová, D., Dömény, Z., Gemeiner, P., Malovíková, A., and Šturdík, E. Reactors for continuous primary beer fermentation using immobilised yeast. Biotechnol. Tech. 11:261-264, 1997.

20. Tata, M., Bower, P., Bromberg, S., Duncombe, D., Fehring, J., Lau, V., Ryder, D., and Stassi, P. Immobilized yeast bioreactor systems for continuous beer fermentation. Biotechnol. Prog. 15:105-113, 1999.

21. van Iersel, M. F. M., van Dieren, B., Rombouts, F. M., and Abee, T. Flavour formation and cell physiology during the production of alcohol-free beer with immobilized Saccharomyces cerevisiae. Enzyme Microb. Technol. 24:407-411, 1999.

22. Vicente, A. A., Meinders, J. M., and Teixeira, J. A. Sizing and counting of Saccharomyces cerevisiae floc populations by image analysis using an automatically calculated threshold. Biotechnol. Bioeng. 51:673-678, 1996.

23. Vicente, A. A., Dluhy, M., Ferreira, E. C., and Teixeira, J. A. Modelling diffusion-reaction phenomena in yeast flocs of Saccaromyces cerevisiae. Bioprocess Eng. 18:335-342, 1998.

24. Virkajärvi, I., and Kronlöf, J. Long-term stability of immobilized yeast columns in primary fermentation. J. Am. Soc. Brew. Chem. 56:70-75, 1998.

25. Virkajärvi, I., and Pohjala, N. Primary fermentation with immobilized yeast: Some effects of carrier materials on the flavour of the beer. J. Inst. Brew. 106:311-318, 2000.

[Received August 26, 2003. Accepted October 20, 2003.] 